\title{
Students and Retirement Saving Predictors
}

\author{
Chris Kalin \\ Wells Fargo Bank, Los Angeles, USA
}

\author{
Oliver Schnusenberg \\ The University of North Florida, USA
}

\begin{abstract}
Over the past century, Americans have had significant increases in personal income yet personal savings has decreased. The researchers examine college students' habits and beliefs concerning saving for retirement. To our knowledge, no study has examined retirement savings among Americans in this age group. We try to determine whether a student's retirement savings beliefs and habits can be predicted. Using a unique survey, five indexes are constructed to assess students' risk-aversion level, financial background, general savings habits, financial literacy, and attitudes toward saving. This index is used to predict a similarly constructed index of retirement savings behavior. We find that our overall model is predictive of a student's beliefs and habits in regards to saving for retirement. In addition, the student's level of risk-aversion, savings beliefs and financial literacy were each independently predictive of retirement savings behavior. Various demographic influences on the constructed risk and savings variables as well as interactions are also investigated.
\end{abstract}

Keywords: retirement savings, financial literacy, risk aversion, students

\section{Introduction and Motivation}

The purpose of this study is to investigate the savings behavior of American students via a survey instrument. This study contributes to the existing literature in several ways. First, no study to date has investigated the factors affecting the savings behavior of American college students. From an educational viewpoint, such an investigation is important because it could indicate a need for further education in the area or personal finance beginning at the high school level.

Second, we develop a model that identifies relevant predictors for the savings behavior among college students. This could reveal new and exciting areas for future research. Furthermore, an understanding of relevant predictors might also result in focusing financial education on certain segments the population to increase the savings rate. Lusardi (2008) finds that offering financial education increase both financial and total net worth sharply for families with low education. Moreover, Lusardi also finds that retirement seminars increase total wealth for both high and low education families.

While previous studies have investigated the different demographic influences on savings behavior and savings behavior as a whole, no previous study has investigated what factors related to upbringing and predisposition to risk-taking affect a person's retirement savings behavior. Investigating college students is particularly useful to accomplish this purpose since this is the population that will shortly enter the workforce and should begin saving for retirement. Thus, identifying the factors that affect this group's retirement savings

Chris Kalin, senior analyst, Wells Fargo Bank.

Oliver Schnusenberg, Ph.D., associate professor of finance, Department of Accounting and Finance, Coggin College of Business, The University of North Florida. 
behavior can shed additional light on the education needed to achieve a comfortable retirement.

\section{Review of Related Literature}

Most Americans would prefer to retire sooner than later, yet few actually have developed a plan to achieve this goal. Over the past century, Americans have seen huge increases in personal income. From 1980 to 2005, personal income rose $265 \%$, yet there has been no increase in personal savings. In fact, savings have decreased with the rise of personal income. People often come up with excuses such as "I have bills to pay now”, “I can't afford to save”, or "I can always save for retirement later". For most Americans, saving for retirement does not become an important objective until they are in their 50s, at which time it may be too late to accumulate a significant amount of wealth (Hennessy, 2006; Hrung, 2002). Indeed, as pointed out by Mitchell and Utkus (2004) surveys repeatedly find that fewer than $40 \%$ of US workers have calculated how much they will need during retirement, $30 \%$ have not saved anything for retirement, and only $20 \%$ feel very confident about having enough money to live comfortably in retirement (Employee Benefit Research Institute (EBRI), 2003).

All workers today need to plan for retirement even more than prior generations. Ettorre (1995) finds that workers are currently saving about 1/3 of that required for a comfortable retirement. The Congressional Budget Office has conducted studies and revealed that a substantial portion of today's workers are not saving enough to cover even their basic needs in retirement.

Although many individuals claim that we have the strongest economy in the world, we are the only country with a negative personal savings rate. As shown in Figure 1, in the early 1980s, America's personal savings rate was well over $10 \%$. Since that time, the savings rate has fluctuated greatly. Figure 1 also illustrates that the personal savings rate appears to increase during recessions, with a very pronounced spike during the recent global financial crisis. On average, however, the savings rate is rather low, and some authors point out that Americans spend more than they earn each year (Alford, Farnen, \& Schachet, 2004; Ettorre, 1995; Schieber, 2004).

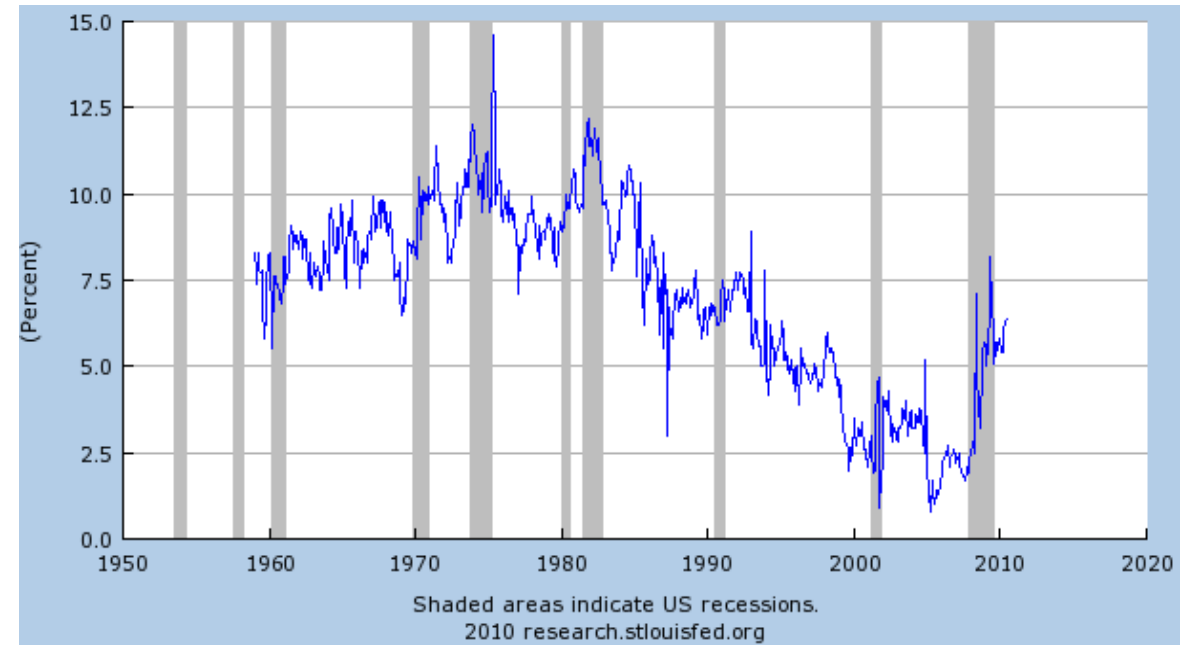

Figure 1. Personal saving rate (PSAVERT). Source: U.S. Department of Commerce: Bureau of Economic Analysis.

Saving early is the key to retirement wealth accumulation. By saving early, an individual can greatly reduce the percentage of their income that they must save each year to achieve a comfortable retirement, one where they do not struggle to meet their basic needs. This is due to the phenomenon known as compound interest, earning interest on interest, which significantly decreases the total savings that must be contributed by the investor if he 
or she begins investing early. By implementing a saving strategy at a young age, when the total dollar amount will likely be small, the investor forms a habit which will likely continue throughout their working years as their income increases. Although the total dollar amount of savings may be higher among people with higher incomes, Dynan (2004) noted that the savings rate is not tied to income (19-2) (Schieber, 2004; Keister, 2003).

Zhong (1994) found that "Older people save more than younger people... more educated people save more than less educated people” (13-8). Yet, those who actually save are often still not rich in retirement. This is because employees tend to choose investments that are less risky. Bischopink (1994) found that the majority of those who participate in retirement savings plans are slow to accumulate wealth because they tend to choose conservative investments with low returns rather than placing their money with professional investment managers who take on more risk but achieve higher returns. Employees chose conservative investments because they are scared of the greater potential loss that comes with riskier investments. This demonstrates the importance of saving early. By saving early, the investor can afford to take on more risk as they have more years to recover any losses. When examined over longer time periods (i.e., ten to twenty years), higher risk investments tend to have higher returns than less risky investments (Hoesly, 1995).

There are three main sources of income in retirement. Retirement income comes from personal savings including Individual Retirement Accounts, employer-sponsored plans such as the defined benefit (pension) and defined contribution (401k or 403b) plans, and social security.

Expenses in retirement are different from expenses in the working years. In retirement, there are no social security taxes to be paid, less spending on food as most have more time to cook meals at home, less clothing expenses and less mortgage expenses. The amount saved from certain expenses not incurred in retirement are often still not enough to cover the significantly increased medical expenses retirees face (Scholz, Seshadri, \& Khitatrakun, 2006).

Today, more than ever, it is vital that Americans begin to think about retirement savings. In the past, the primary option for retirement saving was the defined benefit plan such as a pension plan. Under such plans, the employer provides a predetermined amount to the employee every year after retirement. Many workers prefer the defined benefit plan because under such plans the employer, not the employee, is responsible for assuring that adequate money has been set aside to fund retirement payments to its retirees. Historically, the majority of workers relied solely on the company pension to fund their retirement needs. In 1980, 90\% of all retirement savings were put into defined benefit plans.

Recently, there has been a major shift away from the traditional defined benefit plans toward defined contribution plans such as the 401(k) and IRA. Under defined contribution plans the employee, not the employer, must first off choose whether or not they want to save for retirement, secondly determine how much they need to save to adequately fund their expenses in retirement and thirdly chose the direction that their money is invested. From 1992 to 1998, the number of employees covered by a defined benefit plan dropped from $40 \%$ to 20\% while those enrolled in a defined contribution plan jumped from $37 \%$ to $57 \%$. In $1999,88 \%$ of all retirement savings contributions were to defined contribution plans (Wise, 2006; Bischopink \& Meister, 1994).

A major difference between the defined benefit and defined contribution plans is evidenced in the structure of payments distributed in retirement. An employee covered by a defined benefit plan is guaranteed retirement income from the employer until he or she dies. Whether the retiree lives one year after retirement or forty, they are guaranteed a certain amount of income each year. Alternatively, under a defined contribution plan the retiree has to determine how to make the balance of their account at retirement last their entire life; 
Often a difficult task as it is impossible to know exactly how many years after retirement one will live. If the investor lives longer than they had calculated, they run out of money and are forced to bare the consequences.

Another reason why now more than ever workers need to plan early for retirement is due to the significant population of baby boomers. Baby boomers include anyone born between 1946 and 1964 . Those 76 million Americans born in this eighteen year window make up nearly one-third of the entire United States population. Soon, there will be a major change in the mix of workers to retirees as "every eight seconds another baby boomer turns 55 years old” (16-1). Although the current mix of workers to retirees is 3.3 to 1 , the 2006 OASDI Trustees report indicates that by the time all the baby-boomers have reached age 65 in 2030, the ratio of workers to retirees will only be 2.2 to 1 . With fewer workers paying into the system and more retirees drawing benefits, the current system will fail unless strategic changes are implemented.

There is evidence to suggest that the baby boomers have not saved enough for retirement. Wysocki (1995) in the Wall Street Journal says that, “boomers earning $\$ 100,000$ will need $\$ 653,000$ in today's dollars to retire at 65 in comfort but are only saving about 31\% of the amount needed” (18-2). Bernheim (1996) found that baby boomer households were saving only one-third the amount necessary to be adequately prepared for retirement. Even if Social Security and Medicare do not run out as projected, baby boomers are still not saving enough for retirement (Hennessy, 2006; Alford et al., 2004; Ettorre, 1995; Scholz et al., 2006; Schieber, 2004).

The uncertainty of the current Social Security system is another reason workers must plan sooner for retirement. Though the program is under-funded and its future is serious doubt, many workers still feel that Social Security will support them in retirement. If there are no changes in the current system, Social Security and Medicare taxes, which are currently at $6.2 \%$ on the first $\$ 94,200$ and $1.45 \%$ on any additional income will need to be raised to $28 \%$ of an employee's paycheck by 2030. This means that an average worker in the $28 \%$ federal tax bracket will have to be pay nearly $60 \%$ of their income in taxes to support the current system. $80 \%$ of workers mistakenly believe that even if the system stays funded, the amount they will receive from Social Security will be enough to support the majority of their retirement. The OASDI monthly statistics report for June 2010 reveals that the average retiree receives \$1,069.20 per month from Social Security, or just under $\$ 13,000$ per year. This is not enough to be the sole source of retirement income for most retirees (http://www.ssa.gov/policy/docs/quickfacts/stat_snapshot/) (Selnow, 2003; Ettorre, 1995; Atchley, 1998).

A major factor that causes Americans to place little value on saving early for retirement is the lack of financial literacy possessed by the general population. Students are never required to educate themselves on personal finance. Once they enter the workforce, they will likely not take the time to become more financially literate and will not adequately prepare for their retirement.

Workers may find themselves confused or overwhelmed at the number of retirement savings options available to them. They may get frustrated and ignore the topic of investing until a later time. Bischopink's (1994) study revealed that employers who educate employees about the plans available to them will have a higher percentage of workers who participate in the plans. Selnow (2003) also notes that "People aware of the need to save and familiar with investment options are more likely to set aside money for later" (13-8). Workers who are not educated often have false expectations about retirement and the amount they need to save before they get there (Atchley, 1998; Alford et al., 2004).

There are also psychological factors that play a role in a person's decision to not save early, or adequately, for retirement. For most people, it is more satisfying to spend now rather than save for an uncertain future. In doing this, they are choosing pleasure now over long term pain. We are an instant gratification society and the 
benefits of saving for retirement can not be realized in the short-term. Selnow (2003) noted that it is tough "to promote within the labor force a willingness to set aside scarce resources for some distant age that the worker may or may not reach, for rewards that the worker may or may not achieve, at a price today that the worker may or may not wish to pay” (13-3). Young workers feel that they will always be young. Many workers view retirement savings as a gamble and wonder why they should save when they might not even make it to retirement. To add to the uncertainty, the markets might crash causing them to be worse off than if they had never saved at all.

While there is no immediate tangible reward for saving for retirement and no immediate penalty for not, the future benefits are great and the future penalties are severe. Finke (2006) studied time preference in relation to saving for retirement and found that those who value retirement place a high value on future consumption. His study revealed the strong correlation between preventative behavior and saving for retirement. He noted that those who wear seatbelts, exercise, and read nutrition labels are more likely to save for retirement than those who do not. In addition, he discovered that a low proportion of smokers and drug users save for retirement. Also, he found that those who receive greater utility from taking part in risky behavior tend to place less emphasis on saving for retirement. As noted by Finke, time preference for money and risk-aversion levels are significant predictors of the importance a person places on saving for retirement (Hennessy, 2006; Selnow, 2003; Hoesly, 1995).

Keister (2003) found that the number of siblings a person has is a significant predictor of the importance one places on saving for retirement. The more siblings one has, the less time each child has devoted exclusively to them from their parents. Parents with more children tend to save less and have less time to educate each child about saving. Also, the more siblings one has the less likely their parents are to pay for college, give them a car, or put the down payment on their first home. This causes them to have to pay for these items with no financial assistance from their parents. They are forced to start their finances off in debt and once someone is in debt, they often remain there for the rest of their lives. In addition, the more siblings one has the less likely they are to receive an inheritance when their parents pass away. Keister finds that overall, the more siblings one has the less wealth accumulation they are likely to achieve.

One of the primary retirement savings vehicles available today is the $401(\mathrm{k})$ plan. These plans were made available after the 1978 legislation and are defined contribution plans which qualify under section 401(k) of the Internal Revenue Code. Although they are fairly new in relation to other retirement savings plans, 401(k) plans are now the most popular tax subsidy in the United States. Unlike the IRA, the 401(k) is employment based, meaning you can only contribute to the plan of your current employer.

$401(\mathrm{k})$ plans are gaining popularity as they allow the employee to contribute up to $25 \%$ of their pre-tax salary, up to $\$ 15,500$ in 2008 , to the plan. Interest is earned on that pre-tax money and taxes are not paid until the time of withdrawal. By contributing to a 401(k) plan, employees actually lower the amount they pay in federal taxes each year as their reported income reflects the deduction they have placed in their 401(k). For example, a worker in the $28 \%$ tax bracket who decides to place the maximum allowed $(\$ 15,500)$ into his or her 401(k) plan would save $\$ 4,500$ per year in federal taxes.

These plans are also a wise investment as most employers will match the employees’ contribution. On average, the employer will match $3 \%$ of an employee's salary placed into the plan. That equates to an automatic $100 \%$ return on investment with no risk. Someone earning $\$ 50,000$ a year contributing only $3 \%$ will place $\$ 1,500$ a year in their $401(\mathrm{k})$ plan. In addition, the employer will place another $\$ 1,500$ in the form of a company match into the plan raising the total to $\$ 3,000$ per year being placed into the plan.

As seen in Table 1, Wise (2006) found that 401(k) participation rates are directly linked to age and 
earnings. Despite the wide availability of 401(k) plans, there are many employees who still do not participate. In order to achieve higher participation among employees, many employers are choosing to use automatic enrollment. Under this option, all new employees are automatically enrolled in the 401(k) plan unless they choose to opt-out. This has proven to be an effective way to increase participation as many employees never sign up for the 401(k) plan because they do not know how or do not want to take the time fill out the paperwork. Studies conducted by Selnow (2003) reveal that 9 out of 10 employees automatically enrolled in a 401(k) plan were still enrolled 6 months later. In addition, participation numbers remain 1/3 higher after 3 years than those not under an automatic enrollment plan.

Table 1

401(k) Participation by Age and Earnings (Percent)

\begin{tabular}{llllll}
\hline \multirow{2}{*}{ Age } & \multicolumn{5}{c}{ Annual earnings } \\
\cline { 2 - 6 } & $<\$ 25 \mathrm{~K}$ & $\$ 25 \mathrm{~K}-\$ 50 \mathrm{~K}$ & $\$ 50 \mathrm{~K}-\$ 100 \mathrm{~K}$ & $>$ \$100K & All \\
\hline$<35$ & 25 & 49 & 60 & 62 & 40 \\
$35-50$ & 29 & 55 & 66 & 74 & 48 \\
$50-65$ & 31 & 55 & 69 & 73 & 49 \\
All & 28 & 54 & 66 & 72 & 46 \\
\hline
\end{tabular}

Note. Source: David A Wise "Financing Retirement: The Private Sector".

Choi, Laibson and Madrian (2004) studied 3 firms using automatic enrollment. He found that 401(k) participation at all three firms exceeded $85 \%$. This is because people tend to choose the path of least resistance; those who are enrolled in a 401(k) plan are likely to stay enrolled and those not enrolled are likely to remain not enrolled.

Investment choices within the 401(k) plan have become easier than ever. One option is to choose lifecycle funds. These funds are well diversified within the investor's choice of asset allocation. Some investors are confused as to how they should allocate their assets between stocks, bonds and cash. Life cycle funds make this easy for the investor. The investor simply chooses their target retirement year and chooses a lifecycle fund that is close to that date. For example, a 33 year old in 2008 who wishes to retire at age 65 would choose a 2040 lifecycle fund. These funds will automatically adjust the allocation within the investor's portfolio based on how many years they have remaining until retirement, taking this pressure off of the worker (Engelhardt, 2000; Wise, 2006; Bischopink, 1998; Selnow, 2003).

Over the past twenty years, the Employee Benefit Research Institute has annually conducted what is known as the Retirement Confidence survey. This survey has revealed the poor state of America in regards to retirement savings. The findings from the 2006 survey are shocking.

It is important to complete a retirement needs calculation so that you know how much you need to save to retire comfortably. $72 \%$ report that they are saving for retirement yet only $42 \%$ have ever done a retirement needs calculation. The retirement needs calculation provides great insight and 59\% of workers save more for retirement after completing a retirement needs calculation as they realize what they thought would sustain them in retirement will not be enough.

A majority (52\%) of those who are currently saving for retirement have less than $\$ 50,000$ in total savings and investments while three-fourths of those not currently saving for retirement have less than $\$ 10,000$ in total assets and investments. This figure is even more startling when it comes to young workers. Of all workers age 25-34, 84\% have total savings (not including their primary residence and any defined benefit plans) valued at less than \$50,000.

Though the average worker expects to retire at age 65, the average current retiree retired at age 62 . These 
numbers are up from just 10 years ago when the average worker expected to retire at age 62 while the average retiree retired at age 60 . This proves that many have an unrealistic expectation of how long they can actually work. The reality is that $38 \%$ of workers leave the workforce earlier than they planned. $40 \%$ of these had to leave because of health reasons and $30 \%$ were forced to leave due to downsizing. A mere $12 \%$ of those who leave the workforce early offer only positive reasons for leaving.

Though $24 \%$ of those surveyed say that they are very confident that they will be financially secure at retirement, $22 \%$ of these are not currently saving anything for retirement. Of the $24 \%$ who are very confident they will have saved enough money when they reach retirement, $39 \%$ have less than $\$ 50,000$ in savings, 32\% do not have an IRA and 37\% have not even attempted a retirement needs calculation! Unless they plan on winning the lottery, these workers who are not saving and still are very confident that they will be financially secure in retirement are likely misguided.

The employer sponsored retirement plan is very important in an individual's retirement savings. Employer provided retirement savings plans significantly increase the likelihood of an employee saving. $70 \%$ of workers report that more than $50 \%$ of their total retirement savings are in an employer sponsored plan.

After compiling the results, the Retirement Confidence survey concluded that there are certain factors that have a strong correlation with the saving for retirement. The likelihood of saving for retirement increases with household income, education and health status. Married workers are more likely to save than unmarried workers, those over 35 are more likely than younger workers, homeowners are more likely than non-homeowners, those who have received retirement planning education within the past year are more likely than those who have not and those who have attempted a retirement needs calculation are more likely than those who have not to be saving for retirement.

While only $12 \%$ of pre-retirees say that they will need the same or higher income in retirement than they do in their working years, $55 \%$ of current retirees reported that they need the same or higher income that they earned in their working years. 59\% of current retirees are not covered by any employer-sponsored health insurance plan and have to pay for all of their medical expenses from their own savings. $37 \%$ of current retirees reported that inflation has affected them more than they thought it would, another reason why it is crucial to complete a retirement needs calculation. Though $67 \%$ of pre-retirees expect that they will work and earn pay during their retirement, only $27 \%$ of current retirees actually report working for pay during retirement. For most workers, the saving has to be done before retirement.

In regards to the Social Security system, a mere $6 \%$ of workers are very confident that the Social Security benefits they will receive in retirement will be at least what today's retirees receive while $34 \%$ are not confident at all. Only 5\% of workers are very confident that Medicare will provide them at least the coverage that is received by today's retirees receive while $28 \%$ are not confident at all.

Given that the savings rate reported in Figure 1 has increased, one would expect the results from the 2010 Retirement Confidence Survey to be better. However, the numbers in the 2010 report are virtually indistinguishable from the report in 2006 and are even worse in certain cases. For example, while the 2006 report concluded that $72 \%$ are saving for retirement, that number has dropped to $69 \%$ in 2010 . Additionally, more than $50 \%$ of workers state that their total savings and investment (excluding defined benefit plans and their primary residence) is less than $\$ 25,000$.

These findings from the Retirement Confidence Survey reveal that Americans have a long way to go in regards to retirement savings. Many workers are going to be in for a big shock when they realize that retirement is 
just around the corner and it is too late to save. The sooner one plans, the more comfortable their retirement will be.

\section{Data and Methodology}

A total of 163 students at an AACSB-accredited institution in Florida were recruited for participation in a survey. The 88 question survey instrument was given during the summer of 2007. Students volunteered to take part in a study of "Retirement Savings Predictors in College Students". In exchange for their participation, students received extra credit toward their course grade in the introductory undergraduate corporate finance course. Three students provided nonsensical answers and were eliminated from the analysis, leaving a final sample of 160 students. Informed consent was obtained through electronic signature from all participants. All participants were treated in accordance with the Ethical Principles of Psychologists and Code of Conduct.

Table 2

Descriptive Characteristics of the Sample $(n=160)$

\begin{tabular}{|c|c|c|c|c|c|}
\hline Gender & Percentage & Married & Percentage & Finance major & Percentage \\
\hline Male (0) & 50.6 & Yes (1) & 14.4 & Yes (1) & 23.8 \\
\hline Female (1) & 49.4 & No $(0)$ & 85.6 & No $(0)$ & 76.2 \\
\hline Political orientation & Percentage & Employed & Percentage & Raised in the U.S. & Percentage \\
\hline Conservative (1) & 36.2 & Work full time (1) & 29.4 & Yes (1) & 86.9 \\
\hline Other $(0)$ & 63.8 & Not employed full time (0) & 70.6 & No $(0)$ & 13.1 \\
\hline Children & Percentage & Siblings & Percentage & GPA & Percentage \\
\hline $0(0)$ & 88.1 & $0(0)$ & 9.4 & $<2.0(0)$ & 0.6 \\
\hline $1-2(1)$ & 10.6 & $1-2(1)$ & 68.8 & $2.1-2.5(1)$ & 13.8 \\
\hline \multirow[t]{3}{*}{$3-4(2)$} & 1.2 & $3-4(2)$ & 17.5 & 2.6-3.0 (2) & 46.2 \\
\hline & & 5 or more & 4.4 & 3.1-3.5 (3) & 31.2 \\
\hline & & & & $3.6-4.0(4)$ & 8.1 \\
\hline Mean & 0.1312 & & 1.1688 & & 3.3250 \\
\hline Median & 0.0000 & & 1.0000 & & 3.0000 \\
\hline Age & Percentage & Total debt & Percentage & 401(k) & Percentage \\
\hline $18-21(1)$ & 31.2 & $\$ 0(0)$ & 23.1 & Employer offers (1) & 46.9 \\
\hline $22-25(2)$ & 43.1 & $\$ 1-\$ 2,500(1)$ & 16.2 & Employer does not offer (0) & 53.1 \\
\hline $26-30(3)$ & 18.8 & $\$ 2,501-\$ 10,000(2)$ & 21.9 & & \\
\hline $31-35(4)$ & 5.0 & $\$ 10,001-\$ 25,000(3)$ & 18.1 & & \\
\hline $36-40(5)$ & 1.2 & $>\$ 25,000(4)$ & 20.6 & & \\
\hline$>40(6)$ & 0.6 & & & & \\
\hline Mean & 2.0375 & & 1.9688 & & \\
\hline Median & 2.0000 & & 2.0000 & & \\
\hline
\end{tabular}

The descriptive statistics for the sample based on the demographic questions of the survey are displayed in Table 2. As shown in Table 2, there was about an even gender split, with $49 \%$ females and $51 \%$ males. Also as expected, over $74 \%$ of the students are between 18 and 25 years old, and only $14 \%$ of them are married (about $12 \%$ of the sample has children). About $24 \%$ of the sample majored in finance, and $77 \%$ of the sample has a GPA between 2.6 and 3.5. Only $29 \%$ of the sample is employed full-time, ${ }^{1}$ but $47 \%$ of those working full-time

\footnotetext{
${ }^{1}$ Only about $11 \%$ of the sample indicated that they do not work at all. The vast majority work part-time.
} 
or part-time have employers that offer 401(k) plans. Most frequently, students in the sample do not have debt (23\%), while $21 \%$ of the sample has more than $\$ 25,000$ in debt. Notably, about $36 \%$ of the students in the sample have a conservative political orientation. Although not displayed in Table 2, 97\% of those surveyed were juniors or seniors.

Participants completed 5 independent measures. These included the students' level of risk aversion, financial background, general savings behavior, financial literacy and general savings beliefs. The risk aversion scale included nine items. Responses to each of the questions were either Likert-type or forced choice. Risk-aversion questions included "In general, would you consider yourself a thrill-seeker?" This scale was designed to determine whether or not the student's level of risk-aversion could be used to predict the value they place on saving for retirement.

Next, participants completed the financial background scale which contained four items. Responses to each of the questions were either Likert-type or forced choice. Questions in this category included "Was your family financially constrained when you were growing up?” This scale was designed to determine whether or not a student's financial upbringing is predictive of the value they place on saving for retirement.

Then, participants completed the general savings behavior scale which contained seven items. Responses to each of the questions were either Likert-type or forced choice. Questions included "Do you save money on a frequent basis (for example, quarterly, monthly or weekly)?” This scale was designed to see if a student's current savings habits can predict whether or not they will be saving for retirement.

Next, participants completed the financial literacy scale which contained ten items. Responses to each of the questions were either Likert-type or forced choice. To assess the student's financial literacy, participants were asked to respond to such questions as "I am familiar with most of the savings options and vehicles available today”. This scale was designed to test whether or not a student's level of knowledge regarding financial products such as the 401(k) and IRA can be used to predict the value they will place on saving for retirement.

Finally, participants completed the general savings beliefs scale which contained seventeen items. Responses to each of the questions were either Likert-type or forced choice. This section included such questions as "I feel guilty when I do not save”. This scale was developed to determine whether or not a student's general savings beliefs, aside from their habits, can predict the value they place on saving for retirement.

The dependent variable was the student's retirement savings habits and beliefs. Participants completed this scale which contained twenty-two items. Responses to each of the questions were either Likert-type or forced choice. This scale included questions such as "At what age do you believe a person should begin to save for retirement?" This scale incorporated both the student's beliefs toward retirement savings as well as their actual savings behavior.

The responses to each question were assigned a numerical value. For each of the six categories of questions, the scores were then aggregated for each student. The scoring was conducted in such a manner that the resulting scales were as follows: A higher score on the risk-aversion scale indicated a less risk-averse person; a higher score on the financial background scale indicated the student had greater exposure to sound financial upbringing; a higher score on the general saving habits scale indicated that the student is currently saving more; a higher score on the financial literacy scale indicated that the student has a greater knowledge of savings options available; a higher score on the general savings beliefs scale indicated that the student believes that saving is important, regardless of whether or not they are actually saving; and a higher score on the retirement savings habits and beliefs scale indicated that the student places a higher value on saving for retirement. 
Table 3

Correlations of Demographic Variables and Six Financial Indexes

\begin{tabular}{|c|c|c|c|c|c|c|c|c|c|c|c|c|c|c|c|c|c|c|c|}
\hline & $\begin{array}{l}\text { Risk } \\
\text { aversion }\end{array}$ & $\begin{array}{l}\text { Financial } \\
\text { back- } \\
\text { ground }\end{array}$ & $\begin{array}{l}\text { Savings } \\
\text { beliefs }\end{array}$ & $\begin{array}{l}\text { Financial } \\
\text { literacy }\end{array}$ & $\begin{array}{l}\text { General } \\
\text { savings } \\
\text { habits }\end{array}$ & $\begin{array}{l}\text { Retirement } \\
\text { savings } \\
\text { habits }\end{array}$ & Gender & Age & GPA & Married & $\begin{array}{l}\text { Finance } \\
\text { major }\end{array}$ & $\begin{array}{l}\text { Child- } \\
\text { ren }\end{array}$ & Debt & $\begin{array}{l}\text { Conser- } \\
\text { vative }\end{array}$ & $\begin{array}{l}\text { Full- } \\
\text { time } \\
\text { employ- } \\
\text { ment }\end{array}$ & Income & $\begin{array}{l}\text { U.S. } \\
\text { Raised }\end{array}$ & $\begin{array}{l}\text { Sib- } \\
\text { lings }\end{array}$ & $\begin{array}{l}\text { Employer } \\
\text { offers } \\
401(\mathrm{k})\end{array}$ \\
\hline Risk aversion & 1.000 & & & & & & & & & & & & & & & & & & \\
\hline $\begin{array}{l}\text { Financial } \\
\text { background }\end{array}$ & 0.009 & 1.000 & & & & & & & & & & & & & & & & & \\
\hline $\begin{array}{l}\text { Savings } \\
\text { beliefs }\end{array}$ & 0.132 & 0.114 & 1.000 & & & & & & & & & & & & & & & & \\
\hline $\begin{array}{l}\text { Financial } \\
\text { literacy }\end{array}$ & 0.123 & 0.016 & $0.389^{* *}$ & 1.000 & & & & & & & & & & & & & & & \\
\hline $\begin{array}{l}\text { General } \\
\text { savings } \\
\text { habits }\end{array}$ & $-0.214^{* *}$ & $0.218^{* *}$ & $0.197^{*}$ & 0.138 & 1.000 & & & & & & & & & & & & & & \\
\hline $\begin{array}{l}\text { Retirement } \\
\text { savings } \\
\text { habits }\end{array}$ & 0.114 & 0.024 & $0.217^{* *}$ & $0.263^{* *}$ & $0.348^{* *}$ & 1.000 & & & & & & & & & & & & & \\
\hline Gender & -0.108 & -0.013 & $-0.206^{* *}$ & $-0.228^{* *}$ & 0.124 & 0.085 & 1.000 & & & & & & & & & & & & \\
\hline Age & 0.133 & $-0.215^{* *}$ & 0.149 & $0.210^{* *}$ & 0.050 & $0.184^{*}$ & -0.091 & 1.000 & & & & & & & & & & & \\
\hline GPA & -0.051 & 0.076 & $0.264^{* *}$ & $0.241^{* *}$ & $0.187^{*}$ & -0.008 & 0.035 & 0.118 & 1.000 & & & & & & & & & & \\
\hline Married & -0.086 & -0.127 & 0.148 & $0.280^{* *}$ & 0.137 & 0.152 & 0.023 & $0.413^{* *}$ & $0.225^{* *}$ & 1.000 & & & & & & & & & \\
\hline $\begin{array}{l}\text { Finance } \\
\text { major }\end{array}$ & 0.019 & -0.032 & -0.030 & 0.060 & -0.005 & 0.106 & -0.081 & 0.040 & -0.130 & 0.023 & 1.000 & & & & & & & & \\
\hline Children & -0.114 & -0.131 & 0.146 & $0.244^{* *}$ & 0.050 & 0.034 & 0.088 & $0.408^{* *}$ & 0.144 & $0.572^{* *}$ & 0.040 & 1.000 & & & & & & & \\
\hline Debt & 0.024 & $-0.162^{*}$ & 0.051 & 0.126 & 0.077 & $0.199^{*}$ & -0.013 & $0.377^{* *}$ & -0.090 & $0.378^{* *}$ & $0.164^{*}$ & $0.251^{* *}$ & 1.000 & & & & & & \\
\hline Conservative & -0.043 & 0.093 & 0.095 & 0.143 & 0.069 & 0.077 & -0.095 & -0.139 & -0.060 & 0.025 & $0.160^{*}$ & 0.083 & -0.110 & 1.000 & & & & & \\
\hline $\begin{array}{l}\text { Full-time } \\
\text { employment }\end{array}$ & -0.070 & -0.108 & 0.113 & $0.195^{*}$ & 0.044 & $0.171^{*}$ & -0.006 & $0.348^{* *}$ & -0.087 & $0.244^{* *}$ & -0.005 & $0.288^{* *}$ & $0.298^{* *}$ & -0.058 & 1.000 & & & & \\
\hline Income & 0.008 & -0.145 & $0.261^{* *}$ & $0.240^{* *}$ & 0.102 & $0.226^{* *}$ & 0.000 & $0.564^{* *}$ & 0.080 & $0.605^{* *}$ & 0.095 & $0.423^{* *}$ & $0.502^{* *}$ & 0.009 & $0.543^{* *}$ & 1.000 & & & \\
\hline U.S. raised & 0.028 & -0.054 & -0.086 & -0.007 & 0.018 & 0.120 & -0.023 & -0.043 & -0.093 & -0.105 & $-0.218^{* *}$ & $-0.161^{*}$ & -0.098 & $0.178^{*}$ & -0.074 & -0.023 & 1.000 & & \\
\hline Siblings & 0.023 & -0.150 & 0.090 & 0.044 & -0.011 & $0.171^{*}$ & 0.110 & 0.041 & 0.142 & $0.169^{*}$ & -0.101 & 0.064 & 0.133 & -0.036 & 0.023 & 0.136 & 0.044 & 1.000 & \\
\hline $\begin{array}{l}\text { Employer } \\
\text { offers } 401(k)\end{array}$ & -0.085 & -0.113 & 0.138 & 0.110 & 0.021 & 0.112 & -0.101 & 0.134 & -0.066 & 0.151 & -0.053 & $0.173^{*}$ & $0.245^{* *}$ & 0.021 & $0.384^{* *}$ & $0.417^{* *}$ & -0.013 & 0.068 & 1.000 \\
\hline
\end{tabular}

The correlations between the six indexes just described and the various demographic variables are displayed in Table 3. The following relationships are statistically significant at least at the $5 \%$ level. Students with a high degree of risk aversion tend to have less than \$2,500 in debt. Moreover, less risk-averse individuals are typically raised in the U.S. and are conservative in their political orientation. Also, students with less risk aversion do not display good general savings habits.

Students who are risk averse tend to exhibit well-pronounced general savings habits, which is encouraging. Students' financial background is also positively associated with general savings habits. Interestingly, older students and students with less debt seem to have less of a financial background. Those students that believe saving in general is important tend to be financially literate, have good general and retirement savings habits, have a higher income and a higher GPA. Moreover, believing that saving is important appears to be more pronounced for male students.

Those students that are financially literature are also mostly male. They have a higher GPA, are older, and are more likely to be married with children. They are more likely to work full-time and have a higher income. Lastly, financially literature students have better retirement savings habits and beliefs.

If a student exhibits good general savings habits, that student is likely to have better retirement savings habits and to have a higher GPA. Similarly, those students with good retirement savings habits are older, have more debt, 
are more likely to work full-time and have a higher income, and are more likely to have siblings. This makes sense, since these students probably observed how difficult it is to save for retirement by their parents' example.

In addition to the items already mentioned when discussing the correlations thus far, older students are more likely to be married, to have children, and to have more debt. They also have a higher income and are more likely to work full-time.

Married students also appear to have a higher GPA. Given the time constraints of going to school, this is interesting. However, maybe for a married student to enter into a time commitment by going back to school is positively correlated with the seriousness of their studies. These students are older, more financially literate, have a higher GPA, and more likely to work full-time with a higher income. They are also more likely to have siblings.

The correlations for finance majors are a little disappointing. There are no correlations between the finance majors and any of the six created savings and risk indices. However, finance majors tend to have more debt and are more politically conservative. Generally, those students with more debt have less of a financial background, and are older and married with children, and are more likely to work for employers who offer a 401(k).

In summary, the correlations reported in Table 3 confirm what one would expect in terms of correlations. However, two correlations are interesting: (1) the finding that male students are more financially literature, and (2) the finding that finance majors appear to not reap any practical value from their education.

\section{Empirical Results}

In order to further investigate the relationships between the various variables, we first conduct a variety of $t$-tests to investigate significant differences between groups. Next, we regress the retirement savings index on the risk aversion, financial background, savings beliefs, financial literacy, and general savings habits indexes for several different groups. Lastly, we conduct ANOVA analyses to investigate the impact of variable interactions.

Table 4, Panel A presents the results for $t$-tests for differences in means for all six constructed indexes. A $t$-statistic is computed for each of the demographic variables. Panel B presents Levene's $F$-test for equality of variances. If the difference in variances in Panel B is significant, the computations in Panel A assume unequal variances.

The first row in Table 4, Panel A displays the $t$-tests for retirement savings habits. Several significant differences can be identified. Students older than 25 , married, with incomes greater than $\$ 30,000$ annually who work full-time have better retirement savings beliefs and habits than their counterparts. This finding is not surprising, since employed individuals are more able to save for retirement, the need for which is even more pronounced when married.

Those students that have a better financial background as a result of their upbringing tend to have less debt and fewer children. It is also interesting that these students tend to be younger. Perhaps, due to their upbringing, they are more aware of the financial obligations associated with have children. Maybe younger students have a better financial background because of the increasing media-coverage of financial instruments in recent years.

The findings for general savings beliefs are very pronounced. It seems that males greater than 25 years old, married or with a high GPA value savings more. Moreover, savings beliefs are also more pronounced for students who work full-time for employers, earning more than $\$ 30,000$ per year, that offer $401(\mathrm{k})$ s. This largely confirms the results previously reported in Table 3. The last row of Table 4, Panel A indicates that students who exhibit good general savings habits also tend to be older, have relatively high GPA and are married. Interestingly, while it appears that those students working full time believe that savings is important, they don't seem to do so in practice. 
Table 4

Tests for Differences in Means and F Tests for Equality of Variances Between Demographic Characteristics and Savings Variables

\begin{tabular}{|c|c|c|c|c|c|c|c|c|c|c|c|c|c|}
\hline & 401(k) & Siblings & $\begin{array}{l}\text { US } \\
\text { raised }\end{array}$ & Income $^{b}$ & $\begin{array}{l}\begin{array}{l}\text { Full-time } \\
\text { employment }\end{array} \\
\end{array}$ & Conservative & $\operatorname{Debt}^{\mathrm{c}}$ & Children & $\begin{array}{l}\begin{array}{l}\text { Finance } \\
\text { major }\end{array} \\
\end{array}$ & Married & $\mathrm{GPA}^{\mathrm{d}}$ & Age $^{e}$ & Gender \\
\hline $\begin{array}{l}\text { Retirement } \\
\text { savings } \\
\text { habits }\end{array}$ & 1.414 & $1.665^{*}$ & 1.519 & $3.297 * * *$ & $2.186 * *$ & 0.973 & $1.913 *$ & 0.056 & 1.337 & $1.939 *$ & 0.128 & $2.110^{* *}$ & 1.070 \\
\hline $\begin{array}{l}\text { Risk } \\
\text { Aversion }\end{array}$ & -1.071 & 0.288 & 0.348 & -0.059 & -0.883 & -0.544 & 0.179 & -1.190 & 0.241 & -1.088 & -0.257 & 0.196 & -1.370 \\
\hline $\begin{array}{l}\text { Financial } \\
\text { background }\end{array}$ & -1.429 & -1.252 & -0.681 & -1.164 & -1.370 & 1.169 & $-1.751 *$ & $-1.659 *$ & -0.400 & -1.609 & 0.875 & $-3.268^{* * *}$ & -0.157 \\
\hline $\begin{array}{l}\text { Savings } \\
\text { beliefs }\end{array}$ & $1.746 *$ & -0.008 & -1.085 & $2.885 * * *$ & 1.432 & 1.200 & -0.353 & $1.797^{*}$ & -0.382 & $1.878^{*}$ & $2.127^{* *}$ & $2.663^{* * *}$ & $-2.651^{* * *}$ \\
\hline $\begin{array}{l}\text { Financial } \\
\text { literacy }\end{array}$ & 1.396 & -0.300 & -0.090 & $3.371 * * *$ & $2.505^{* *}$ & $1.813^{*}$ & 0.336 & $3.042 * * *$ & 0.757 & $3.672^{* * *}$ & $2.172^{* *}$ & $3.314 * * *$ & $-2.939 * * *$ \\
\hline $\begin{array}{l}\text { General } \\
\text { savings } \\
\text { habits }\end{array}$ & 0.265 & -1.222 & 0.222 & 1.131 & 0.552 & 0.872 & 0.767 & 0.578 & -0.066 & $1.738 *$ & $2.599 * * *$ & $1.760^{*}$ & 1.570 \\
\hline \multicolumn{14}{|c|}{ Panel B: F test for equality of variances ${ }^{a}$} \\
\hline & 401(k) & Siblings & $\begin{array}{l}\text { US } \\
\text { raised }\end{array}$ & Income $^{b}$ & $\begin{array}{l}\text { Full-time } \\
\text { employment }\end{array}$ & Conservative & $\operatorname{Debt}^{\mathrm{c}}$ & Children & $\begin{array}{l}\text { Finance } \\
\text { major }\end{array}$ & Married & $\mathrm{GPA}^{\mathrm{d}}$ & Age $^{e}$ & Gender \\
\hline $\begin{array}{l}\text { Retirement } \\
\text { savings } \\
\text { habits }\end{array}$ & 1.241 & 0.107 & 0.025 & 0.024 & 0.502 & 0.077 & $4.228 * *$ & 0.045 & 1.580 & 0.186 & $5.579 * *$ & 0.628 & 0.120 \\
\hline $\begin{array}{l}\text { Risk } \\
\text { aversion }\end{array}$ & 0.116 & 1.370 & 0.068 & 0.024 & 0.028 & 0.042 & 0.000 & 0.883 & 0.061 & 0.265 & 1.489 & 1.146 & 0.031 \\
\hline $\begin{array}{l}\text { Financial } \\
\text { background }\end{array}$ & 0.295 & $4.414^{* *}$ & $3.543^{*}$ & $12.994 * * *$ & $5.563^{* *}$ & 0.005 & 0.624 & 1.638 & 0.072 & $10.901 * * *$ & 0.019 & $6.490 * *$ & $3.239 *$ \\
\hline $\begin{array}{l}\text { Savings } \\
\text { beliefs }\end{array}$ & $10.982 * * *$ & 0.290 & 0.690 & 1.184 & 1.002 & 0.109 & 2.519 & 3.993** & 0.289 & $3.032 *$ & $3.897 * *$ & 0.341 & 0.248 \\
\hline $\begin{array}{l}\text { Financial } \\
\text { literacy }\end{array}$ & 0.022 & 2.079 & 0.152 & 0.942 & 1.262 & 0.055 & 0.566 & 0.336 & 0.419 & 0.284 & 1.569 & 1.887 & 0.401 \\
\hline $\begin{array}{l}\text { General } \\
\text { savings } \\
\text { habits }\end{array}$ & 0.579 & 1.297 & 0.016 & 0.510 & 1.133 & 0.005 & 0.887 & 0.015 & 0.557 & 0.005 & 0.045 & 0.081 & 0.745 \\
\hline
\end{tabular}

Notes. ${ }^{*}$ Significant at the $10 \%$ level. ${ }^{* *}$ Significant at the $5 \%$ level. ${ }^{* *}$ Significant at the $1 \%$ level. ${ }^{\text {a }}$ For the demographic variables 401(k), Siblings, US raised, Full-time employment, Conservative, Children, Finance major, Married, and Gender, the groups were defined using a yes or no format. For example, the $t$-test for 401(k) is the difference in the indexes of the left-most column for those whose employers offer a 401(k) and the index value for those whose employers do not offer a 401(k). The first group is always the affirmative group. The first group for Gender is female. ${ }^{\mathrm{b}}$ The first group for Income is those making more than $\$ 30,000$ a year; the second group is everyone else. ${ }^{c}$ The first group for Debt is those with more than $\$ 2,500$ in debt; the second group is everyone else. ${ }^{\mathrm{d}}$ The first group for GPA is those with a GPA greater than 3.0; the second group is everyone else. ${ }^{\mathrm{e}}$ The first group for Age is those older than 25; the second group is everyone else.

The findings for financial literacy are interesting. First, those students earning more than $\$ 30,000$ a year, with children, married, with a higher GPA are more financially literate. Additionally, older students and male students also appear to be more financially literate. The most interesting finding is perhaps that politically conservative students are more financially literate than those with other political orientations. Interestingly, risk aversion does not seem to differ across any of the demographic groups investigated here.

Thus far, we have investigated the relationship between the six constructed risk and savings variables and the demographic variables. In order to investigate the direct relationship between our five predictor variables (risk aversion, financial background, savings beliefs, financial literacy and general savings habits) and the dependent variable (retirement savings habits and beliefs), we conduct regressions for the entire sample and for various subsamples based on the demographic variables. The regression results are presented in Table 5 through Table 9. 
Table 5

Regression Results Based on Gender

\begin{tabular}{lcc}
\hline Entire sample; $n=160, F=7.78^{* * *}$, Adjusted $r$ squared $=0.18$ & \\
\hline Predictor & Coefficient & $t$-statistic \\
\hline Risk aversion & 0.673 & $2.16^{* *}$ \\
Financial background & -0.193 & -0.90 \\
Savings beliefs & 0.257 & 0.83 \\
Financial literacy & 0.293 & $2.14^{* *}$ \\
General savings habits & 0.454 & $4.65^{* * *}$ \\
\hline Female sample; $n=79, F=4.38^{* * *}$, Adjusted $r$ squared $=0.18$ & \\
\hline Predictor & Coefficient & $t$-statistic \\
\hline Risk aversion & 0.182 & 1.64 \\
Financial background & -0.156 & -1.47 \\
Savings beliefs & 0.174 & 1.47 \\
Financial literacy & 0.061 & 0.507 \\
General savings habits & 0.378 & $3.18^{* * *}$ \\
\hline Male sample; $n=81, F=4.42^{* * *}$, Adjusted $r$ squared $=0.18$ & \\
\hline Predictor & Coefficient & $t$-statistic \\
\hline Risk aversion & 0.773 & $1.74^{*}$ \\
Financial background & 0.167 & 0.48 \\
Savings beliefs & 0.050 & 0.12 \\
Financial literacy & 0.510 & $2.67^{* * *}$ \\
General savings habits & 0.443 & $2.99^{* * *}$ \\
\hline
\end{tabular}

Notes. ${ }^{*}$ Significant at the $10 \%$ level. ${ }^{* *}$ Significant at the $5 \%$ level. $* * *$ Significant at the $1 \%$ level. Source: Regression results are from predicting retirement savings behavior from general savings habits, financial literacy, financial background, risk aversion, and savings beliefs.

The first panel in Table 5 presents the regression results for the entire sample of 160 students. As shown in Table 5, financial literacy and general savings habits are positive and significant predictors of retirement savings habits. This makes sense, as more financially literate students and students who are already saving understand the importance of saving for retirement. Interestingly, the less risk-averse a student is, the more he or she will save for retirement, on average. Given that our sample consists of relatively young students, they may be investing primarily in equities when saving for retirement, which could explain their lack of risk aversion.

The next panel of Table 5 shows the results for female student and male students. For female students, only general savings habits are positively associated with greater retirement savings. For male students, risk aversion, financial literacy, and general savings habits are significantly associated with greater retirement savings.

Table 6 presents the regression results by age and GPA. It is interesting to note that the regression results for students older than 25 and 25 or younger mirror those for female students and male students, respectively. For students with a GPA greater than 3.0, risk aversion, financial literacy, and general savings habits result in higher retirement savings or at least the belief that saving for retirement is important. For students with a lower GPA, the results are almost identical, but risk aversion apparently does not affect retirement savings. 
Table 6

Regression Results Based on Age and GPA

\begin{tabular}{|c|c|c|}
\hline Predictor & Coefficient & $t$-statistic \\
\hline Risk aversion & 0.362 & 0.61 \\
\hline Financial background & -0.348 & -0.90 \\
\hline Savings beliefs & 0.570 & 0.84 \\
\hline Financial literacy & 0.226 & 0.88 \\
\hline General savings habits & 0.710 & $3.47 * * *$ \\
\hline \multicolumn{3}{|c|}{ Age $<=25 ; n=119, F=4.00^{* * *}$, Adjusted $r$ squared $=0.11$} \\
\hline Predictor & Coefficient & $t$-statistic \\
\hline Risk aversion & 0.751 & $2.01 * *$ \\
\hline Financial background & -0.092 & -0.32 \\
\hline Savings beliefs & 0.146 & 0.40 \\
\hline Financial literacy & 0.291 & $1.68 *$ \\
\hline General savings habits & 0.363 & $3.16^{* * *}$ \\
\hline \multicolumn{3}{|c|}{ GPA $>3.0 ; n=63, F=4.41^{* * *}$, Adjusted $r$ squared $=0.22$} \\
\hline Predictor & Coefficient & $t$-statistic \\
\hline Risk aversion & 1.231 & $2.14^{* *}$ \\
\hline Financial background & 0.041 & 0.10 \\
\hline Savings beliefs & -0.418 & -0.81 \\
\hline Financial literacy & 0.483 & $2.14 * *$ \\
\hline General savings habits & 0.661 & $3.52 * * *$ \\
\hline \multicolumn{3}{|c|}{ GPA $<=3.0 ; n=97, F=5.33^{* * *}$, Adjusted $r$ squared $=0.18$} \\
\hline Predictor & Coefficient & $t$-statistic \\
\hline Risk aversion & 0.447 & 1.26 \\
\hline Financial background & -0.333 & -1.40 \\
\hline Savings beliefs & 0.959 & $2.46^{* *}$ \\
\hline Financial literacy & 0.078 & 0.45 \\
\hline General savings habits & 0.361 & $3.32 * * *$ \\
\hline
\end{tabular}

Notes. ${ }^{*}$ Significant at the $5 \%$ level. *** Significant at the $1 \%$ level. Source: Regression results are from predicting retirement savings behavior from general savings habits, financial literacy, financial background, risk aversion, and savings beliefs.

Table 7 presents the results for finance majors and debt levels. For finance majors, less risk aversion and general savings habits result in greater saving for retirement. For non-finance majors, financial literacy and general savings habits have the same effect. For finance majors, maybe this implies a correct understanding or interpretation of the risk/return relationship.

The findings for debt presented in the second to last panel of Table 7 are very interesting. For students with more than $\$ 2,500$ in debt, financial literacy and general savings habits are positively associated with greater retirement savings. However, for students with less than $\$ 2,500$ in debt, less risk aversion and general savings habits exhibit a positive relationship. Within the group of 63 students with little or no debt, apparently less risk aversion has 
a positive impact on retirement savings. It stands to reason that these students are probably very risk averse (given that they have no debt), so that even a slight decrease in risk aversion has a positive impact on retirement savings.

Table 7

Regression Results Based on Major and Debt Level

\begin{tabular}{lcc}
\hline Finance major; $n=38, F=2.62^{* *}$, Adjusted $r$ squared $=0.18$ & \\
\hline Predictor & Coefficient & $t$-statistic \\
\hline Risk aversion & 1.396 & $1.76^{*}$ \\
Financial background & -0.235 & -0.44 \\
Savings beliefs & -0.112 & -0.12 \\
Financial literacy & 0.183 & 0.51 \\
General savings habits & 0.812 & $2.84^{* * *}$ \\
\hline
\end{tabular}

Not finance major; $n=122, F=5.32 * * *$, Adjusted $r$ squared $=0.15$

\begin{tabular}{lcc}
\hline Predictor & Coefficient & $t$-statistic \\
\hline Risk aversion & 0.461 & 1.34 \\
Financial background & -0.234 & -0.96 \\
Savings beliefs & 0.290 & 0.89 \\
Financial literacy & 0.327 & $2.16^{* *}$ \\
General savings habits & 0.387 & $3.75^{* * *}$ \\
\hline
\end{tabular}

Debt $>\$ 2,500 ; n=97, F=4.92 * * *$, Adjusted $r$ squared $=0.17$

\begin{tabular}{lcc}
\hline Predictor & Coefficient & $t$-statistic \\
\hline Risk aversion & 0.262 & 0.76 \\
Financial background & -0.216 & -0.94 \\
Savings beliefs & 0.156 & 0.41 \\
Financial literacy & 0.374 & $2.32^{* *}$ \\
General savings habits & 0.376 & $3.26^{* * *}$ \\
\hline
\end{tabular}

Debt $<=\$ 2,500 ; n=63, F=3.35^{* * *}$, Adjusted $r$ squared $=0.16$

\begin{tabular}{lcc}
\hline Predictor & Coefficient & $t$-statistic \\
\hline Risk aversion & 1.411 & $2.33^{* *}$ \\
Financial background & 0.047 & 0.105 \\
Savings beliefs & 0.339 & 0.650 \\
Financial literacy & 0.124 & 0.504 \\
General savings habits & 0.541 & $3.04^{* * *}$ \\
\hline
\end{tabular}

Notes. * Significant at the $10 \%$ level. ${ }^{* *}$ Significant at the $5 \%$ level. ${ }^{* * *}$ Significant at the $1 \%$ level. Source: Regression results are from predicting retirement savings behavior from general savings habits, financial literacy, financial background, risk aversion, and savings beliefs.

Table 8 shows the regression results by political orientation and employment status. Table 8 indicates that less risk aversion, greater financial literacy, and more pronounced general savings habits are positively related to retirement savings for politically conservative students, while only general savings habits increase retirement savings for students with other political beliefs. For the conservative students, perhaps the interpretation is similar to the no debt students, in that they may be more risk averse than other students. Table 8 also shows that 
for students who are employed full-time, savings beliefs and general savings habits are good predictors of retirement savings, while risk aversion and general savings habits successfully predict retirement savings behavior for those students that are not employed full-time.

Table 8

Regression Results Based on Political Orientation and Employment Status

\begin{tabular}{|c|c|c|}
\hline Predictor & Coefficient & $t$-statistic \\
\hline Risk aversion & 1.640 & $3.56^{* * *}$ \\
\hline Financial background & -0.112 & -0.33 \\
\hline Savings beliefs & 0.513 & 1.05 \\
\hline Financial literacy & 0.391 & $1.89 *$ \\
\hline General savings habits & 0.280 & $1.82 *$ \\
\hline \multicolumn{3}{|c|}{ Not conservative; $n=102, F=4.85^{* * *}$, Adjusted $r$ squared $=0.16$} \\
\hline Predictor & Coefficient & $t$-statistic \\
\hline Risk aversion & 0.090 & 0.22 \\
\hline Financial background & -0.311 & -1.15 \\
\hline Savings beliefs & 0.082 & 0.21 \\
\hline Financial literacy & 0.222 & 1.23 \\
\hline General savings habits & 0.524 & $4.19 * * *$ \\
\hline \multicolumn{3}{|c|}{ Full-time employed; $n=47, F=7.55^{* * *}$, Adjusted $r$ squared $=0.42$} \\
\hline Predictor & Coefficient & $t$-statistic \\
\hline Risk aversion & 0.515 & 0.91 \\
\hline Financial background & -0.482 & -1.43 \\
\hline Savings beliefs & 1.532 & $2.70 * * *$ \\
\hline Financial literacy & 0.079 & 0.30 \\
\hline General savings habits & 0.743 & $4.53^{* * *}$ \\
\hline \multicolumn{3}{|c|}{ Not full-time Employed; $n=113, F=3.82^{* * *}$, Adjusted $r$ squared $=0.42$} \\
\hline Predictor & Coefficient & $t$-statistic \\
\hline Risk aversion & 1.013 & $2.70 * * *$ \\
\hline Financial background & 0.001 & 0.00 \\
\hline Savings beliefs & -0.106 & -0.29 \\
\hline Financial literacy & 0.252 & 1.54 \\
\hline General savings habits & 0.328 & $2.78 * * *$ \\
\hline
\end{tabular}

Notes. * Significant at the $10 \%$ level; *** Significant at the $1 \%$ level. Source: Regression results are from predicting retirement savings behavior from general savings habits, financial literacy, financial background, risk aversion, and savings beliefs.

Table 9 presents the regression results for students based on income level and whether the employer offers a 401(k) plan. The only notable finding in Table 9 is in the last panel. For students whose employers offer 401(k) plans, savings beliefs, financial literacy, and general savings habits are associated with more savings for retirement, while less risk aversion and general savings habits are significant for those whose employers do not offer a retirement savings plan. Perhaps the more financially literate employees understand the value of saving for retirement better and, given the chance to save by their employer, take more advantage of the opportunity. 
Table 9

Regression Results Based on Income and Retirement Plan Availability

\begin{tabular}{|c|c|c|}
\hline \multicolumn{3}{|c|}{ Income $>=\$ 30,000 ; n=43, F=4.18^{* * *}$, Adjusted $r$ squared $=0.27$} \\
\hline Predictor & Coefficient & $t$-statistic \\
\hline Risk aversion & -0.004 & -0.01 \\
\hline Financial background & -0.159 & -0.54 \\
\hline Savings beliefs & 0.425 & 0.57 \\
\hline Financial literacy & 0.139 & 0.58 \\
\hline General savings habits & 0.607 & $3.47 * * *$ \\
\hline \multicolumn{3}{|c|}{ Income $<\$ 30,000 ; n=117, F=3.52^{* * *}$, Adjusted $r$ squared $=0.10$} \\
\hline Predictor & Coefficient & $t$-statistic \\
\hline Risk aversion & 0.905 & $2.46^{* *}$ \\
\hline Financial background & -0.089 & -0.30 \\
\hline Savings beliefs & 0.159 & 0.45 \\
\hline Financial literacy & 0.224 & 1.31 \\
\hline General savings habits & 0.373 & $3.12 * * *$ \\
\hline \multicolumn{3}{|c|}{ Employer offers 401(k); $n=75, F=6.36^{* * *}$, Adjusted $r$ squared $=0.27$} \\
\hline Predictor & Coefficient & $t$-statistic \\
\hline Risk aversion & 0.571 & 1.39 \\
\hline Financial background & -0.458 & -1.62 \\
\hline Savings beliefs & 1.068 & $2.23 * *$ \\
\hline Financial literacy & 0.355 & $2.04 * *$ \\
\hline General savings habits & 0.359 & $2.95 * * *$ \\
\hline \multicolumn{3}{|c|}{ Employer does not offer 401(k); $n=85, F=3.34^{* * *}$, Adjusted $r$ squared $=0.12$} \\
\hline Predictor & Coefficient & $t$-statistic \\
\hline Risk aversion & 0.800 & $1.71^{*}$ \\
\hline Financial background & 0.011 & 0.03 \\
\hline Savings beliefs & -0.177 & -0.41 \\
\hline Financial literacy & 0.256 & 1.20 \\
\hline General savings habits & 0.546 & $3.57 * * *$ \\
\hline
\end{tabular}

Notes. * Significant at the $10 \%$ level. ** Significant at the $5 \%$ level. $* * *$ Significant at the $1 \%$ level. Source: Regression results are from predicting retirement savings behavior from general savings habits, financial literacy, financial background, risk aversion, and savings beliefs.

So far, we have only investigated relationships between individual variables and the retirement savings predictors. However, given many of the relationships, it is also important to investigate whether there are any interaction effects of the demographic variables on the six savings and risk constructs. In order to examine this issue, we conducted ANOVA analyses for each possible interaction between the six constructed variables and the demographic variables. The significant interaction effects and their associated constructs are presented in Table 10. The first column of Table 10 identified the significant interaction of two demographic variables; the second column lists the construct the interaction is significant for. Given the relationships identified thus far, we can identify which specific demographic characteristic influences the construct.

Gender appears to have significant interactions with several variables, as shown in the first four rows of Table 10. First, older males apparently especially value savings in general. Second, single males have a better financial background. Males with children and young males are also especially financially literate.

The next variable with a lot of significant interactions with other variables is age. These findings are very interesting. First, young, non-finance majors with a conservative political orientation have a better financial 
background. However, older students with children are more financially literate (perhaps by necessity).

Table 10

Significant Interactions Between Demographic Variables and Six Savings Indexes

\begin{tabular}{llll}
\hline & Variable & $F$ & Significance \\
\hline Gender*Age & Savings beliefs & 2.445 & 0.049 \\
Gender*Married & Financial background & 4.092 & 0.045 \\
Gender*Children & Financial literacy & 4.028 & 0.020 \\
Gender*401(k) & Financial literacy & 4.691 & 0.032 \\
Age*FinMaj & Financial background & 2.651 & 0.035 \\
Age*Children & Financial literacy & 2.630 & 0.026 \\
Age*Political & Financial background & 3.822 & 0.005 \\
GPA*FinMaj & Retirement savings habits & 5.464 & 0.001 \\
Married*Conservative & General savings habits & 4.939 & 0.028 \\
FinMaj*Debt & Retirement savings habits & 7.187 & 0.008 \\
FinMaj*Conservative & Risk aversion & 2.434 & 0.050 \\
FinMaj*Siblings & Financial literacy & 3.951 & 0.049 \\
Children*401(k) & Risk aversion & 2.838 & 0.040 \\
Debt*Income & Financial literacy & 4.548 & 0.035 \\
\hline & Savings beliefs & 2.815 & 0.000
\end{tabular}

The findings for finance majors are also interesting in terms of their interaction. Finance majors with a GPA greater than 3.0 apparently understand the importance of retirement savings. Moreover, finance majors with more than \$2,500 in debt and finance majors with siblings are less risk averse. This could simply indicate that finance majors understand financial relationships and, consequently, they realize that leveraging has risk associated with it.

There are three other interesting relationships in Table 10. First, married and politically conservative students exhibit better retirement savings habits. Second, students with children whose employers offer a 401(k) are more financially literate, perhaps by necessity of constraints naturally imposed by having children. Third, students earning more than $\$ 30,000$ a year with no debt believe that saving is very important. ${ }^{2}$

\section{Summary and Conclusion}

The overall model containing the student's risk-aversion level, financial background, general savings habits, financial literacy and general savings beliefs is predictive of the student's retirement savings. The student's risk-aversion level is predictive of the student's retirement savings independent of the overall model. This is to be expected because someone who is a risky individual would likely not be saving for retirement since not saving for retirement is certainly a big risk. Also, the students' general savings habits are predictive of their retirement savings independent of the overall model. This is important because the views a student has toward saving in general will shape his or her views toward saving for retirement. Additionally, and perhaps most importantly, the student's financial literacy is a significant predictive factor of their retirement savings in many of the models analyzed here. If the student does not know what options are available to them, or if they

${ }^{2}$ Interestingly, the interaction term was not significantly related to actual savings behavior. 
are confused by the number of retirement savings products, they are likely not going to save.

Certain variable are not significant independently in predicting a student's retirement savings. One is the student's general saving behavior. Even though a student may have an implemented saving strategy for their income now, it does not necessarily translate into an implemented retirement savings strategy. Also, the student's financial background does not predict their retirement savings. A student's financial background does not predispose them to be more or less likely to be saving for retirement. This indicates that you can take a student who grew up with a wealthy family at the beach and a student who grew up in poverty in the inner-city and through proper education, both should be equally as likely to value saving for retirement.

There are certain limitations associated with this study. One is the fact that the investigated institution is a non-traditional school meaning that the average age of students is higher than at a traditional university. Non-traditional students are therefore more likely to be working full-time while pursuing their degree and more likely to already be saving for retirement. Another limitation is that some of the questions may not be assessing the variables correctly. For example, in the risk aversion scale contained questions that assessed the student's risk-aversion level in a round-about way. Questions such as "I smoke regularly" or "I always wear my seatbelt" may not truly assess the student's level of risk-aversion.

In conclusion, further research needs to be conducted. An interesting extension of the results presented here would be to investigate the relationships following the global financial crisis to see its impact on savings behavior in general and savings beliefs in particular. The results presented here imply that education plays an important role in actual retirement savings behavior. Most students are not educated in this area, even if they are finance majors. One approach to increase retirement savings may be to educate students about the benefits of retirement savings, the importance of good general savings habits, and the possible implications to excessive risk taking on the ultimate value of their retirement account.

\section{References}

Alford, S., Farnen, D., \& Schachet, M. (2004). Affordable retirement: Light at the end of the tunnel. Benefits Quarterly, 20 , 7-14.

Atchley, R. C. (1998). Doomsday 2029? Social security projections don't tell the whole story. Journal of the American Society of CLU \& ChFC, 52, 30-34.

Bernheim, B. D. (1996). Is the baby boom generation saving adequately for retirement? Summary report. New York: Merrill Lynch, Pierce, Fenner \& Smith Inc.

Bischopink, J. A., \& Meister, G. G. (1994). Investment education under 401(k) plans. Benefits Quarterly, 10, 33-40.

Choi, J. J., Laibson, D., \& Madrian, B. C. (2004). Plan design and 401(k) savings outcomes. National Tax Journal, 52, $275-298$.

Dynan, K. E., Skinner, J., \& Zeldes, S. P. (2004). Do the rich save more? The Journal of Political Economy, 112, 397-444.

Engelhardt, G. V. (2000, September 29). Have 401(k)s raised household saving? Evidence from the health and retirement study. Syracuse Center for policy research working paper. Retrieved from http://ssrn.com/abstract=285174 or doi:10.2139/ssrn.285174

Employee Benefit Research Institute. (2003). Retirement confidence survey-2003 results. Retrieved from http://www.ebri.org/surveys/rcs/2003/

Employee Benefit Research Institute. (2006). Retirement confidence survey-2006 results. Retrieved from http://www.ebri.org/surveys/rcs/2006/

Employee Benefit Research Institute. (2010). Retirement confidence survey-2010 results. Retrieved from http://www.ebri.org/surveys/rcs/2010/

Ettorre, B. (1995). Heads, you lose. Tails, you don’t win. Management Review, 84(8).

Finke, M. S. (2006). Time preference and the importance of saving for retirement. Retrieved from http://ssrn.com/abstract $=886554$

Hennessey, S. M. (2006). A practical approach to retirement planning. FMI Journal, 15, 26-30. 
Hoesly, M. L. (1995). Alternatives for increasing retirement savings in the US. Journal of the American Society of CLU \& ChFC. 49, 66-71.

Hrung, W. B. (2002). Income uncertainty and IRAs. International Tax and Public Finance, 9, 591-599.

Keister, L. A. (2003). Sharing the wealth: The effect of sibligs on adult's wealth ownership. Demography, 40, 521-542.

Leibfritz, W. (2002). Retiring later makes sense: Organization for economic cooperation and development. The OECD Observer, 234, 36-38

Lusardi, A. (2008). Saving and the effectiveness of financial education. Pension Research Council WP2003-14. Retrieved from http://ssrn.com/abstract=476022 or doi:10.2139/ssrn.476022

Mitchell, O. S., \& Utkus, S. P. (2004). Lessons from behavioral finance for retirement plan design. In O. S. Mitchell, \& S. P. Utkus (Eds.), Pension design and structure: New lessons from behavioral finance. New York: Oxford University Press.

Sarenski, T. (2006). Planning for social security. Journal of Accountancy, 202, 30.

Schieber, S. J. (2004). Retirement income adequacy: Good news or bad? Benefits Quarterly, 20, 27-39.

Scholz, J. K., Seshadri, A., \& Khitatrakun, S. (2006). Are Americans saving “optimally” for retirement? The Journal of Political Economy, 14, 607-643.

Selnow, G. M. (2003). Motivating retirement planning: Problems and solutions. Pension Research Council WP2003-7. Retrieved from http://ssrn.com/abstract=472384 or doi:10.2139/ssrn.472384

The Board of Trustees of the Federal. (2006). Old-age and survivors insurance and disability insurance trust funds. Annual Report. Retrieved from http://www.ssa.gov/OACT/TR/TR06/index.html

Wise, D. A. (2006). Financing retirement: The private sector. Business Economics, 41, 14-20.

Wysocki, B. Jr. (1995, June 5). Binge buyers: Many baby boomer save little, may run into trouble later on: They don’t build nest eggs nearly rapidly enough for an easy retirement. Wall Street Journal, A1.

Yakoboski, P. (2000). Retirement plans, person saving, and saving adequacy. EBRI Issue Brief 219.

Zhong, L. X. (1994). Factors associated with bond and stock holdings. Consumer Interests Annual, 40, 359-360. 